\title{
Impact of Land Use Types and Soil Depths on the Distribution of Soil Physical and Chemical Properties in Soils of Aboy Gara Watershed, at Gidan District, North Wollo Zone, Ethiopia
}

\author{
Gebeyaw T. Y.* \\ Department of Soil and Water Resources Management, Faculty of Agriculture, Woldia University, Woldia, \\ Ethiopia \\ Corresponding Author: *gebeyaw2006@gmail.com
}

https://doi.org/10.36263/nijest.2019.02.0102

\begin{abstract}
The study was conducted at the degraded land soils of the Abuhoy Gara Catchment, which is located in the Gidan District of North Wello Zone, Ethiopia to determine the impact of land use type and soil depth on the distribution of soil physical and chemical properties. Soil samples were collected from representative locations with four replications at two depths, surface $(0-15 \mathrm{~cm})$ and subsurface $(15-30 \mathrm{~cm})$ of cultivated, grazing and bush land use types. One hundred eighty soil samples were collected from the depths of 0-15 and $15-30 \mathrm{~cm}$ each in a radial sampling scheme using an auger. Totally, twelve composite soil samples were collected using flexible grid survey method of 1:30,000 scales. The collected samples were air-dried, homogenized and sieved to pass a $2 \mathrm{~mm}$ mesh sieve for the standard physical and chemical analyses. Results showed that the soil physical and chemical properties were significantly affected by the interaction of land uses and soil depths. Silt content decreases while clay content increases across depth from surface to subsurface soils. The lowest $\mathrm{pH}-\mathrm{H} 2 \mathrm{O}$ was registered at the subsurface soils of the grazing lands, while the highest was recorded at the surface soils of the bush land. The interaction effect of land use by soil depth on the variability of soil organic matter was significantly higher at surface layer of the grazing land and lower at surface layer of cultivated land. Similarly, soil total nitrogen was highest in surface layer of the grazing land, while it was lowest in subsurface layer of the bush land. Exchangeable bases were highest in surface soils of the bush land and lowest in the surface soils of cultivated land. The contents of both exchangeable bases were decreasing with soil depth in all land uses except the bush land. Significant difference in cation exchange capacity contents was observed as highest in surface soil layer of the bush land and lowest in surface soil layer of the cultivated land. From the results of the study, it can be concluded that the interaction of land use with soil depth showed negative effects especially disturbance of soil nutrient status on cultivated land in surface soils. In general, the spatial variability of soil properties indicates the soil conditions were strongly affected by inappropriate land use and soil management practices including soil depth. Therefore, reducing intensity of cultivation, adopting integrated soil fertility management and application of organic fertilizers could maintain the existing soil condition and replenish degraded soil properties.
\end{abstract}

Keywords: Land uses, soil depth, soil physical and chemical properties, watershed

\subsection{Introduction}

Securing food and a livelihood is inextricably linked to the exploitation of the natural resource base (land, water and forest) in Ethiopia, where over 85 percent of the population lives in rural areas and contribute significantly to the total export value (Alemneh, 2003). Land degradation, mainly due to soil erosion and nutrient depletion, has become one of the most important environmental and economic problems in the highlands of Ethiopia (World Bank, 2008). And it was estimated that half of the Ethiopian highlands' arable lands are moderately to severely degraded and nutritionally depleted due to pressure of intense human activity and improper farming and management practices 
such as over cultivation, over grazing, primitive production techniques, and over dependent on rainfall (Hugo et al., 2002). As the interaction between natural and anthropogenic management system persists (Assefa and van Keulen, 2009), soil undergoes vertical exchange of materials which in turn resulted in physical and chemical changes from surface soil to sub-soils (Brady and Weil, 1999).

Human management system such as frequent plowing and tillage for the purpose of cultivation, grazing or similar uses changes the proportions of many soil properties with changing depths (Ali et al., 1997; MacCarthy et al., 2013). According to the report by Islam and Weil (2000), tillage mechanically disintegrates soil particles and modifies soil conditions for plant growth and intensive leaching, and hastens organic matter decomposition. Sheet erosion and intensive leaching process leads to higher concentration of clay content and lesser concentration of calcium, magnesium, potassium and sodium in the subsoil than the topsoil (Adeboye et al., 2011).

Although, as soil quality has emerged as a leading concept in natural resource conservation and protection, the agricultural land area expansion with uncontrolled farming pose serious threats to the sustainability and the suitability of soil for crop production which is based on the quality of the soil's physical, chemical and biological properties. On the other hand, there is no available study that examines dynamics of soil properties under different land covers to establishing appropriate management options and to restoring degraded soils in the highlands. So, stronger emphasis is now being placed on appropriate fertility management technologies to enhance these dynamic soil properties by understanding soil performances. Research investigation in relation to soil fertility status in line with land use and soil depth can provide information on soil suitability for crop production, diagnosing soil constraints for agriculture and improved technique for future rehabilitation program which can serve as a basis for fertilizer recommendations. The outcome of the investigation can provide suitable guidelines for future research on the development of promising conservation technologies and implementation approaches. The objective of the study was to determine the impact of land use types and soil depths on the distribution of soil physical and chemical properties in eroded soils of Aboy Gara watershed.

\subsection{Methodology}

\subsection{Description of the study area}

The study was conducted at Abuhoy Gara catchement in Gidan district (Figure 1) which is found in North Wollo Zone of Amhara National Regional State, Ethiopia. Gidan is bordered by Tigray Region in the North; Gubalafto district in the North east; Meket district in the south east and Lasta district in the south and south west. Astronomically, it is located between $11^{0} 53^{\prime}-12^{0} 16^{\prime}$ North and $39^{0} 10^{\prime}$ 3 $39^{0} 35^{\prime}$ east $39^{0} 10^{\prime}$ _ $39^{0} 35^{\prime}$ East. Muja is the administrative town of the district and is situated at about $595 \mathrm{~km}$ from the capital city, Addis Ababa. According to the district agricultural office report, the population of the study catchment is 580 people of whom 420 are male and 160 are female. The total area of Abuhoy Gara catchment is about 615 hectares (250 hectares cultivated and 365 hectares none cultivated lands). According to North-East Amhara meteorological data service, the mean annual rainfall is $1100 \mathrm{~mm}$ with mean annual maximum and minimum temperature of $21.23^{\circ} \mathrm{C}$ and $9.57^{\circ} \mathrm{C}$, respectively. The topography and land form of the area is dominated by rolling hills dissected streams and valleys. The altitude ranges from 3,089 to 3,559 m.a.s.l (having an average altitude of 3,324 m.a.s.l). The topography of the watershed (i.e., at total of 1819 ha) is characterized as $15 \%$ gentle slopes, $53.6 \%$ steep slope, $31.4 \%$ very steep. The dominant form of agriculture is subsistence farming and livestock keeping. The dominant crops include; wheat, barley and faba bean have been cultivated during the main rainy season. Livestock production is an essential part of the farming system. Most farm households keep cattle dominated by oxen and small stock including sheep, poultry, and equines. 


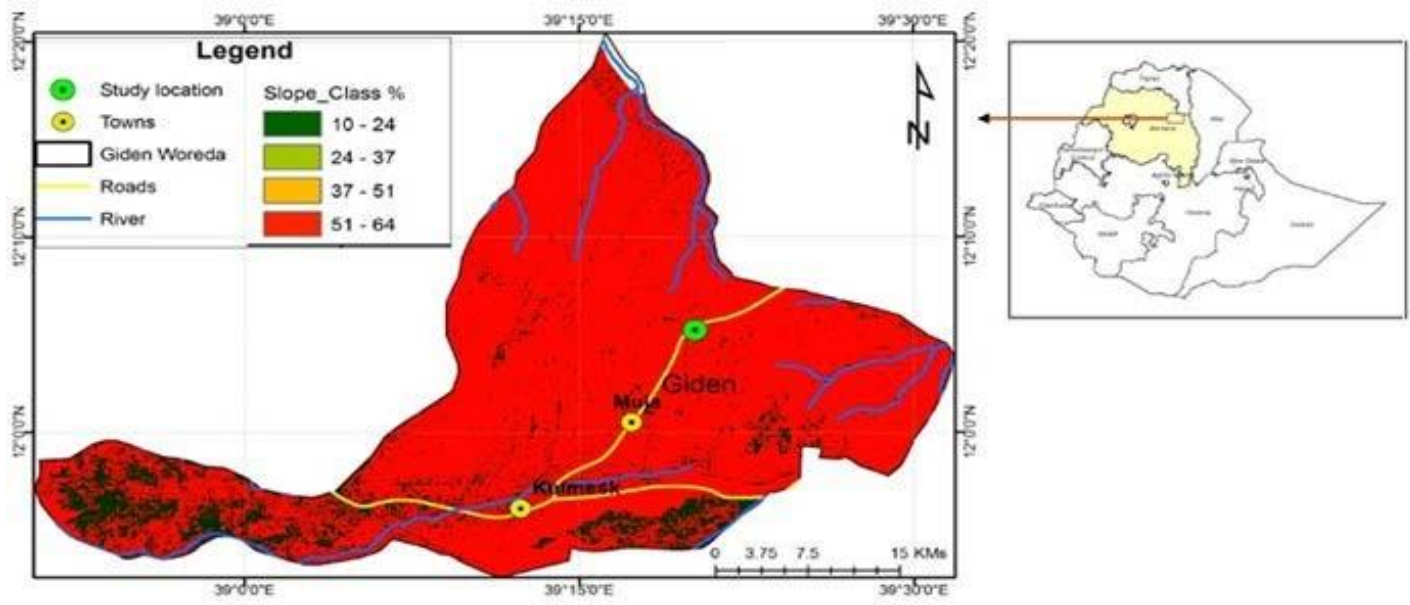

Figure 1: Location Map of the Study Area

\subsection{Methods of data collection}

\subsubsection{Sampling field observation}

At the beginning, a general visual field survey of the area was carried out to have a general view of the variations in the study area. Global Positioning System (GPS) readings were used to identify the geographical locations and the coordinate system where samples were taken, and clinometers were used to identify slopes of the sampling sites. Representative soil sampling fields were then selected based on vegetation and cultivation history and they are categorized bush, grazing and cultivated lands.

\subsubsection{Soil sampling}

Soil samples were collected from representative sampling sites with four replications (higher slope, middle slope, intermediate slope and lower slope positions) from two soil depths of the bush, grazing and cultivated lands representative fields using an auger (Ryan et al., 2001). Totally, twelve composite soil samples from surface $(0-15 \mathrm{~cm})$ and subsurface $(15-30 \mathrm{~cm})$ soil layers were collected using flexible grid survey method of 1:30,000 scales. Each composite sample was made from a pool of fifteen point samples and from the twelve composite soil samples major soil fertility parameters were analyzed. The samples were placed in a numbered calico bag with tightly fitting lid and labeled carefully with the location, representative field and depth of soil. The soil samples collected from representative fields' were then air-dried, mixed well and passed through a $2 \mathrm{~mm}$ sieve for the analysis of selected soil physical and chemical properties. Before sampling, forest litter, grass, dead plants and any other materials on the soil surface were removed and during collection of samples, field/terrace edges, furrow, old manures, wet spots, areas near trees, compost pits, fields used as kitchen gardens and fertilizer bands were excluded.

\subsection{Method of data analyses}

\subsubsection{Soil laboratory analysis}

The collected samples were air-dried, homogenized and sieved to pass a $2 \mathrm{~mm}$ mesh sieve for soil physical and chemical analyses. Particle-size distribution (sand, silt and clay) was determined using bouyoucos hydrometer method procedures (Black et al., 1965). Soil pH was determined using the method reported in McLean, (1982) as follows; $1 \mathrm{~g}$ of soil was dissolved in $2.5 \mathrm{ml}$ of IM solution of potassium chloride. The mixture was stirred intermittently for 1 hour and the resultant $\mathrm{pH}$ was measured using a $\mathrm{pH}$ meter fitted with a glass electrode. The exchangeable acidity present in the soil 
was determined by titration method using $0.01 \mathrm{M}$ sodium hydroxide $(\mathrm{NaOH})$ after extraction with $1 \mathrm{M}$ potassium chloride $(\mathrm{KCl})$ (Sumner and Stewart, 1992). Organic carbon was analyzed by Walkley Black wet digestion method (Bremner and Mulvaney, 1982; Nelson and Sommers, 1982). Soil organic matter was computed by multiplying soil organic carbon by a factor of 1.724 (Baruah and Barthakur, 1997). Total nitrogen was determined using Kjeldahl method (Okalebo et al., 1993). Available phosphorous was analyzed using the Olsen sodium bicarbonate extraction solution ( $\mathrm{pH} 8.5$ ) method (Olsen et al., 1954) and the amount of available phosphorous was measured by spectrophotometer. The concentration of exchangeable cations (calcium, magnesium, potassium, and sodium) present in the soil was determined with the aid of AAS (atomic absorption spectrophotometer; Shimadzu AA-6800) after extraction with 1M Ammonium acetate (NH4OAc) buffered at $\mathrm{pH}$ 7. The cation exchange capacity of the soil was determined by $0.05 \mathrm{M}$ potassium sulphate $\left(\mathrm{K}_{2} \mathrm{SO}_{4}\right)$ using the soil used for the basic exchangeable cation determination or by the neutral ammonium acetate (CH3COONH4) saturation method (Ryan et al., 2001). The exchangeable bases in the ammonium acetate filtrates collected above were measured by atomic absorption spectrophotometer (Ryan et al., 2001).

\subsubsection{Data analysis}

Soil parameter readings were subjected to statistical analysis using; univariate statistics (plot design), interaction plot to view land-use and soil depth effect. On the statistical significance of land-use and soil depth on the soil physical and chemical properties, one way analysis of variance was done. The statistical analysis was implemented using R-studio. When there was statistically significant difference (alpha $=0.05$ level) on single or interaction effect, mean separation was done using $1 \mathrm{~m}$ and cld functions with Tukey's test.

\subsection{Results and Discussion}

\subsection{Soil texture}

Results of the statistical analysis reveal that both silt and clay contents were significantly affected by the interaction of land uses and soil depths $(\mathrm{P} \leq 0.05)$. Likewise, the sand fraction was varied significantly at $(\mathrm{P} \leq 0.05)$ as a result of the interaction of land use and soil depth (Table 1and Figure 1). Considering the interaction effects of land use by soil depth on soil particle fraction distribution, the highest interaction mean of sand $(67.25 \%)$, and silt $(26.50 \%)$ fractions were observed in both surface $(0-15 \mathrm{~cm})$ and subsurface $(15-30 \mathrm{~cm})$ soils of the grazing land compared to cultivated and bush lands. On the other hand, the highest clay content $(25.50 \%)$ was recorded at the subsurface layer of the cultivated land, whereas the lowest $(56.00 \%)$ sand and $(6.25 \%)$ clay contents were observed at the surface layer of cultivated and grazing lands, respectively. Silt content decreases while clay content increases across depth from surface to subsurface soils. The increase in clay contents with depth under all land use types may be due to translocation of clay from surface to subsurface layers, which ultimately increase the proportion of silt content in the surface soil layers $(26.5 \%$ in surface layer of grazing land). The result is in agreement with the findings of Boke (2004) who reported high sand content in grass land soils in Southern Ethiopia.

From the results, it was observed that; there were high differences in particle size distribution in the interaction of land use types with soil depth since these watersheds are highly affected by changes in land management. The result was in agreement with the results reported in Agoume and Birang (2009), who found that land-use systems and soil depths significantly affected the sand, the clay and the silt fractions of the soils size distributions in Cameroon. The clay content of the cultivated land increased with soil depth. This may be due to the intensive and continuous cultivation which might cause the surface that increases translocation of clay particles. This finding is similar that reported in Shiferaw (2004) who reported an increase in clay content with depth under cultivated lands due to long period of cultivation. The highest clay content observed in soils of the cultivated land could be 
attributed to the mixing of soil during tillage activities as was also reported in Heluf and Wakene (2006), Tematio et al. (2011), Aminu et al. (2013) and Aung et al. (2013).This result contradicts with the result reported in Jaiyeoba (2001) were it was observed that the clay content of cultivated land reduces with depth due to the intensive and continuous cultivation which might cause compaction of the surface that reduces translocation of clay particles within the different layers coupled with profile mixing by tillage activities. The highest clay content in the bush land might be due to the effect of soil forming process which can be similar to the report by Buol (1997), that the accumulation of clay in the subsurface horizon could also be contributed by the in situ synthesis of secondary clays or the residual concentration of clays from the selective dissolution of more soluble minerals of coarser grain size in the B horizon.

Table 1: Interaction effect of land use and soil depth on particle size ((sand, silt and clay) distribution of the soils in Abuhoy Gara watershed

\begin{tabular}{|c|c|c|c|c|c|}
\hline \multirow[b]{2}{*}{ Land use types } & \multirow{2}{*}{$\begin{array}{l}\text { Soil depth } \\
\text { (cm) }\end{array}$} & \multicolumn{3}{|c|}{ Soil textural fraction $(\%)$} & \multirow{2}{*}{$\begin{array}{l}\text { Soil textural class } \\
\text { (USDA) }\end{array}$} \\
\hline & & Sand & Silt & Clay & \\
\hline \multirow{3}{*}{ Cultivated } & $0-15$ & $56.0^{\mathrm{a}}$ & $21.0^{\mathrm{b}}$ & $23.0^{\mathrm{cd}}$ & Sandy clay loam \\
\hline & $15-30$ & $59.5^{\mathrm{ab}}$ & $15.3^{\mathrm{a}}$ & $25.5^{\mathrm{d}}$ & Sandy clay loam \\
\hline & $0-15$ & $67.3^{\mathrm{c}}$ & $26.5^{\mathrm{c}}$ & $6.3^{\mathrm{a}}$ & Sandy loam \\
\hline \multirow{3}{*}{$\begin{array}{l}\text { Grazing } \\
\text { Bush land (shrub \& some } \\
\text { trees) }\end{array}$} & $15-30$ & $65.3^{\mathrm{c}}$ & $24.5^{\mathrm{c}}$ & $10.3^{\mathrm{b}}$ & Sandy loam \\
\hline & $0-15$ & $60.0^{\mathrm{ab}}$ & $17.0^{\mathrm{a}}$ & $23.0^{\mathrm{c}}$ & Sandy clay loam \\
\hline & $15-30$ & $60.0^{\mathrm{b}}$ & $16.0^{\mathrm{a}}$ & $24.0^{\mathrm{cd}}$ & Sandy clay loam \\
\hline Land (F value) & & 50.16 & 119.8 & 913.3 & \\
\hline Land $-\operatorname{Pr}(>\mathrm{F})$ & & $4.4 \mathrm{e}-08 * * *$ & $4.0 \mathrm{e}-11 * * *$ & $<2.2 \mathrm{e}-16 * * *$ & \\
\hline Soil depth (F value) & & 0.5 & 34.5 & 41.0 & \\
\hline Soil depth $-\operatorname{Pr}(>\mathrm{F})$ & & $0.48^{\mathrm{ns}}$ & $1.5 \mathrm{e}-05 * * *$ & $5.0 \mathrm{e}-06 * * *$ & \\
\hline $\begin{array}{l}\text { Land use } x \text { Soil depth (F } \\
\text { value) }\end{array}$ & & 4.58 & 8.124 & 7.37 & \\
\hline $\begin{array}{l}\text { Land use } x \text { Soil depth-Pr } \\
(>\mathrm{F})\end{array}$ & & $0.02 *$ & $0.00306 * *$ & $0.005 * *$ & \\
\hline $\operatorname{SEM}(+)$ & & 0.88 & 0.62 & 0.42 & \\
\hline
\end{tabular}

*Interaction means within a specific soil parameter followed by the same letter $(s)$ are not significantly different from each other at $P \leq 0.05$; ‘**’ 0.001; ‘**’ 0.01; ‘*’ 0.05; SEM = Standard Error of Mean
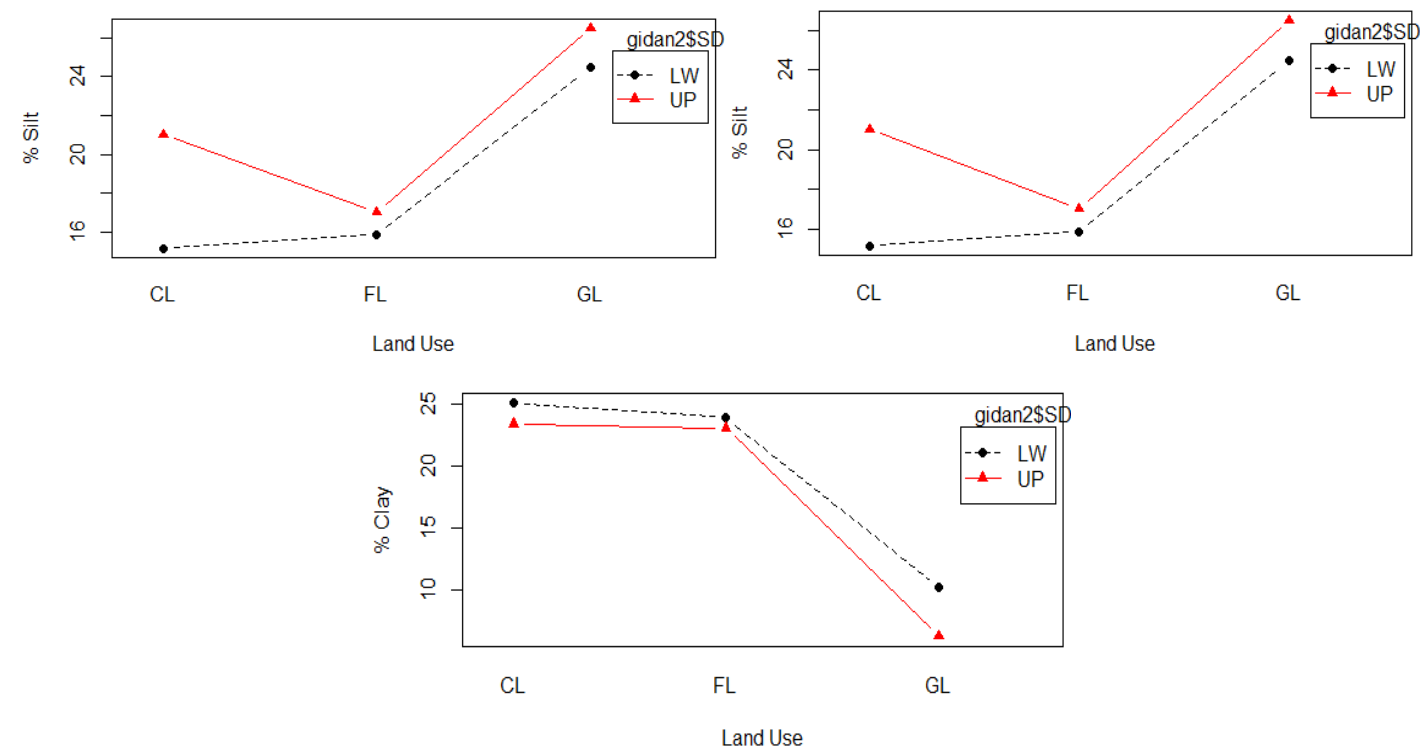

$* L W=$ Subsurface layer; $U P=$ Surface layer, $C L=$ Cultivated land, $F L=$ Bush land, $G L=$ Grazing Land

Figure 1: The effect of land uses and soil depths on particle size distribution 


\subsection{Soil Chemical properties}

\subsubsection{Soil Reaction $(\mathrm{pH})$}

The soils $\mathrm{pH}-\mathrm{H}_{2} \mathrm{O}$ value was significantly affected by the interaction of land uses and soil depths $(\mathrm{P} \leq$ 0.01). The lowest (5.69) $\mathrm{pH}-\mathrm{H}_{2} \mathrm{O}$ was registered at the subsurface layer of the grazing land soils, while the highest (6.71) was recorded at the surface layer of the bush land soils (Table2 and Figure 2). The lowest $\mathrm{pH}$ at the subsurface layer of the grazing land could be the result of high organic matter content, while the highest $\mathrm{pH}$ in the surface layer of the bush land could be the result of accumulation of basic cations. The lowest value of $\mathrm{pH}$ under the surface layer of the cultivated land may be due to two major reasons. The first is the depletion of basic cations in crop harvest and drainage to streams in runoff generated from accelerated erosions. Secondly, it may be due to its highest microbial oxidation that produces organic acids, which provide $\mathrm{H}$ ions to the soil solution and thereby lowers the soil $\mathrm{pH}$. In general, according to study report by Fu, (2000) and ZhaoQ (2008), continuous cultivation practices, excessive precipitation, and application of inorganic fertilizers could be some of the factors which are responsible for the variation in $\mathrm{pH}$ in the soil profiles. The highest $\mathrm{pH}$ observed at the subsurface layer of the cultivated land could be attributed to the leaching of basic cations and soil erosion through tillage as was also reported in Fungo et al. (2011) and Kumar et al. (2012).

Table 2: Land use and soil depth effect on chemical properties of the soils in Abuhoy Gara watershed

\begin{tabular}{lccccc}
\hline Land use types & $\begin{array}{c}\text { Soil } \\
\text { depth } \\
(\mathrm{cm})\end{array}$ & \begin{tabular}{c} 
Selected soil chemical properties \\
\cline { 3 - 5 }
\end{tabular} & $\begin{array}{c}\mathrm{pH} \\
(1: 2.5 \mathrm{H} 2 \mathrm{O})\end{array}$ & $\begin{array}{c}\text { Total } \\
\text { Nitrogen } \%\end{array}$ & $\begin{array}{c}\text { Organic matter } \\
\text { Available Phosphorus } \\
(\text { PPM })\end{array}$ \\
\hline Cultivated & $0-15$ & $5.93^{\mathrm{ab}}$ & $0.121^{\mathrm{ab}}$ & $0.920^{\mathrm{a}}$ & $7.12^{\mathrm{c}}$ \\
& $15-30$ & $6.03^{\mathrm{ab}}$ & $0.104^{\mathrm{ab}}$ & $1.110^{\mathrm{ab}}$ & $7.31^{\mathrm{c}}$ \\
Grazing & $0-15$ & $6.28^{\mathrm{bc}}$ & $0.240^{\mathrm{c}}$ & $2.343^{\mathrm{d}}$ & $3.50^{\mathrm{ab}}$ \\
& $15-30$ & $5.69^{\mathrm{a}}$ & $0.103^{\mathrm{ab}}$ & $1.475^{\mathrm{c}}$ & $4.25^{\mathrm{b}}$ \\
Bush land (shrub \& some trees) & $0-15$ & $6.71^{\mathrm{c}}$ & $0.132^{\mathrm{b}}$ & $1.583^{\mathrm{c}}$ & $3.84^{\mathrm{ab}}$ \\
& $15-30$ & $5.93^{\mathrm{ab}}$ & $0.045^{\mathrm{a}}$ & $1.260^{\mathrm{b}}$ & $2.46^{\mathrm{a}}$ \\
\hline Land (F value) & & 6.397 & 10.9888 & 175.133 & 75.8060 \\
Land -Pr(>F) & & $0.0079662^{* *}$ & $0.0007605^{* * *}$ & $1.592 \mathrm{e}-12^{* * *}$ & $1.707 \mathrm{e}-09^{* * *}$ \\
Soil depth (F value) & & 22.661 & 29.5405 & 72.882 & 0.5393 \\
Soil depth -Pr(>F) & & $0.0001564^{* * *}$ & $3.656 \mathrm{e}-05^{* * *}$ & $9.597 \mathrm{e}-08^{* * *}$ & 0.47217 \\
Land use x Soil depth (F value) & & 8.841 & 5.4932 & 61.147 & 4.3598 \\
Land use x Soil depth Pr$(>\mathrm{F})$ & & $0.0021155^{* *}$ & $0.0137311^{*}$ & $9.421 \mathrm{e}-09^{* * *}$ & $0.02857^{*}$ \\
SEM $( \pm)$ & & 0.1095588 & 0.0182 & 0.04782056 & 0.3488249 \\
\hline
\end{tabular}

*Interaction means within a specific soil parameter followed by the same letter(s) are not significantly different from each other at $P \leq 0.05$; '***’ 0.001; '**'0.01; '*’ 0.05; SEM = Standard Error of Mean

Generally, the $\mathrm{pH}$ values observed in the study area are within the ranges of moderately acidic to neutral soil reactions as indicated by Foth and Ellis (1997). In general, except at cultivated land, pH values decreased with increasing soil depth (Table 2). The reason can be attributed to the reduction of basic caions along soil depth which lowers soil $\mathrm{pH}$ from top to down the soil layers.

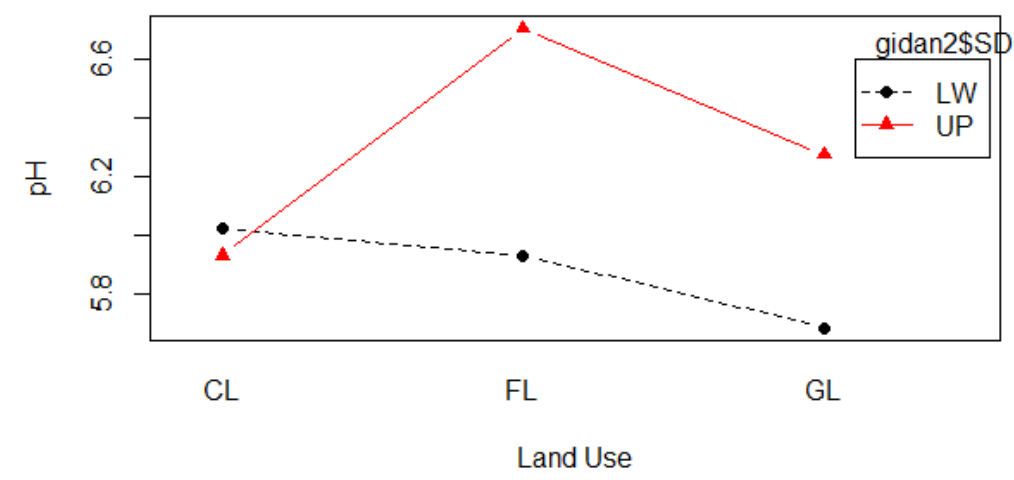

$* * L W=$ Subsurface layer $; U P=$ Surface layer, $C L=$ Cultivated land, $F L=$ Bush land, $G L=$ Grazing Land

Figure 2: The effect of land uses and soil depths on soil $\mathrm{pH}$ 


\subsubsection{Soil Organic Matter $(\mathrm{OM})$ :}

Soil organic matter content was significantly affected by the interaction of land uses with soil depth (P $\leq 0.01$ ) (Table 2 and Figure 3). The interaction effect of land use by soil depth, on the variability of soil organic matter was significantly higher $(2.343 \%)$ at surface layer of the grazing land and lower $(0.920 \%)$ at surface layer of cultivated land (Table 2). Following this, the percentage changes in organic matter content of subsurface soil from surface soil were decreasing in grazing and bush lands uses unlike cultivated land use. This implies that the litter on the soil surface beneath different canopy layers and high biomass production caused high biological activity in the topsoil layers of grazing and bush lands, whereas the depletion organic matter due to intensive cultivation of the land which results the total removal of crop residues for animal feed and source of energy intensifies oxidation of organic matter at cultivated land.

The low organic matter content in the study area might have resulted in insufficient inputs of organic substrate from the farming system due to deforestation, open grazing, residue removal and zero crop rotation as was also reported by Nega and Heluf (2009). The highest change of organic matter with depth under grazing land might be attributed to continuous accumulation of un-decayed and partially decomposed plant and animal residues mainly in the surface soils of forestland, in addition to high rate of interception and infiltration coupled with absence of erosion as reported in Morgan (2005). A similar finding reported in (Urioste et al. (2006) revealed that roots of the grass and fungal hyphae are probably responsible for the high amount of total organic matter in grass land. On the distribution of soil organic matter, Berhanu (1980), reported that the soils in the study area ranges from very low ( $0.92 \%$ in surface soil) in cultivated land to medium $(2.343 \%$ surface soil) in grazing land.

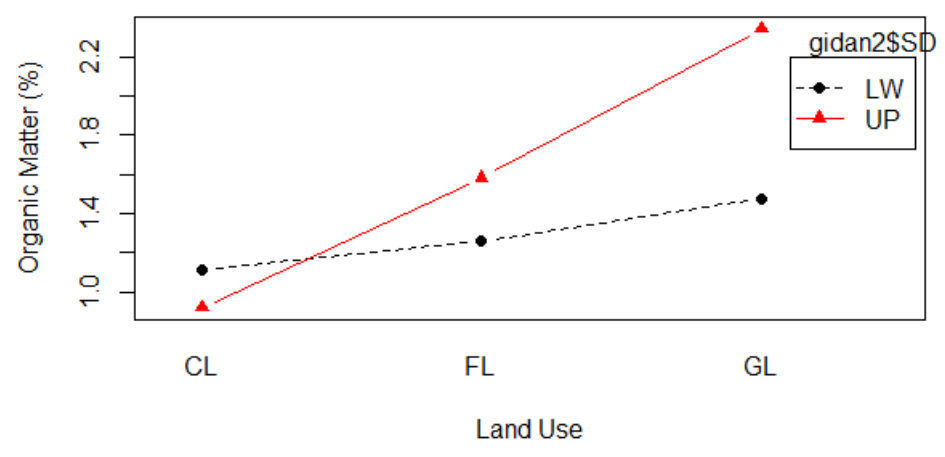

$* L W=$ Subsurface layer; $U P=$ Surface layer, $C L=$ Cultivated land, $F L=$ Bush land, $G L=$ Grazing Land

Figure 3: The effect of land uses and soil depths on organic matter content

\subsubsection{Soil Total Nitrogen}

Similar to organic matter content, the mean total nitrogen content of the soils was also affected by the interaction of land use and soil depth significantly $(\mathrm{P} \leq 0.05)$ (Table 2 and Figure 4). Soil total nitrogen was the highest $(0.240 \%)$ in surface layer of the grazing land, while it was lowest $(0.045 \%)$ in subsurface layer of the bush land (Table 2). The percentage changes in total nitrogen content of subsurface soil from surface soil were decreasing in all land uses. This implies that the surface soil layer is the most biologically active of the soil profile. The highest change of organic matter with depth under bush land might be attributed to continuous accumulation of un-decayed and partially decomposed plant and animal residues mainly in the surface soils of bush land as reported in (Morgan, 2005). Similar to organic matter, the percentage changes in total nitrogen content of subsoil from topsoil were decreasing in all land uses. Thus, total nitrogen is higher in topsoil than in the subsoil probably due to losses in organic matter by mineralization in the subsoil. This is expected because organic matter is the major source of soil organic matter and total nitrogen contents. Results indicate that conversion of the grazing land into cultivated land has resulted in loss of $49.6 \%$ of total nitrogen from the soils. The considerable loss of total nitrogen from soils following conversion of 
land from forest to cultivated land is reported in (Mulugeta et al., 2005; Eyayu et al., 2009; Mojiri et al., 2012). Moreover, as reported by Bahrami et al., (2010); Heshmati et al., (2011); Taye, (2011), lower total nitrogen content was observed in soils of cultivated lands as compared to soils of natural forest lands. According to the classification of soil total nitrogen as per the ranges suggested by Landon (1991) and Tekalign (1991), the soils of the study area are very low to low $(0.103-0.240 \%)$ in total nitrogen content.

All of the studied soils were less than $0.5 \%$ of total nitrogen which might be due to high rates of microbial decomposition and nitrogen transformation took place at the cultivated lands. The change in total nitrogen was highest under grazing this may be due to abundance of legume plants and Azotobacter algae (able to fix atmospheric nitrogen), decaying plant and animal matter, and nitrogen compounds produced by thunderstorms (Hall, 2008). The lowest change of total nitrogen under cultivated land compared to grazing land implies that fertilizer applications may not have replaced the total nitrogen lost due to harvest removal, leaching, and humus losses associated with cultivation (Eyayu et al., 2009).

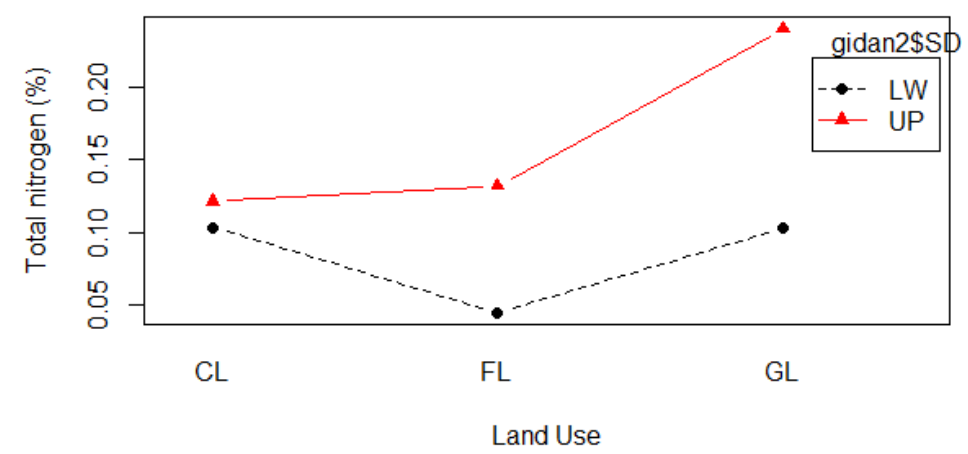

$* L W=$ Subsurface layer $; P=$ Surface layer, $C L=$ Cultivated land, $F L=$ Bush land, $G L=$ Grazing Land

Figure 4: The effect of land uses and soil depths on total nitrogen

\subsubsection{Soil Available Phosphorus}

The available phosphorus was significantly $(\mathrm{P} \leq 0.05)$ affected by the interaction of the two factors (Table 2 and Figure 5). The content of available phosphorus in the cultivated land appeared to be significantly higher than the other two land use types. Available phosphorus was highest $(7.31 \mathrm{ppm})$ in subsurface soil and $(7.12 \mathrm{ppm})$ in surface soil of cultivated land, while it was the lowest (2.46 ppm) subsurface soil under bush land (Table 2). The higher in available phosphorus contents in soils of cultivated land were due to continuous application of mineral phosphorus fertilizer for few years as indicated by different farmers in the area. This was assured by Vander Eijk et al. (2006) that the high content of phosphorus under maize farms than of grass land soils could be due to the continuous application of phosphorus fertilizer applications. Similarly, Boke (2004) also found that high availability of phosphorus under enset farms which is due to rapid mineralization and additions of manure and crop residue.

According to Landon (1991) available soil phosphorus level of $<5 \mathrm{mg} / \mathrm{kg}$ is rated as low, $5-15 \mathrm{mg} / \mathrm{kg}$ as medium and $>15 \mathrm{mg} / \mathrm{kg}$ is rated as high. Thus, the mean available phosphorus content of the soils of the study area, with the exception of both layers of the cultivated land, were less than $5 \mathrm{mg} / \mathrm{kg}$ qualifying for the low range. The soil of the study area are in agreement with the results reported by many authors Murphy (1968), Tekalign et al. (2002) and Abebe and Endalkachew (2012) that the availability of phosphorus under most soils of Ethiopia decline by the impacts of fixation, abundant crop harvest and erosion. 


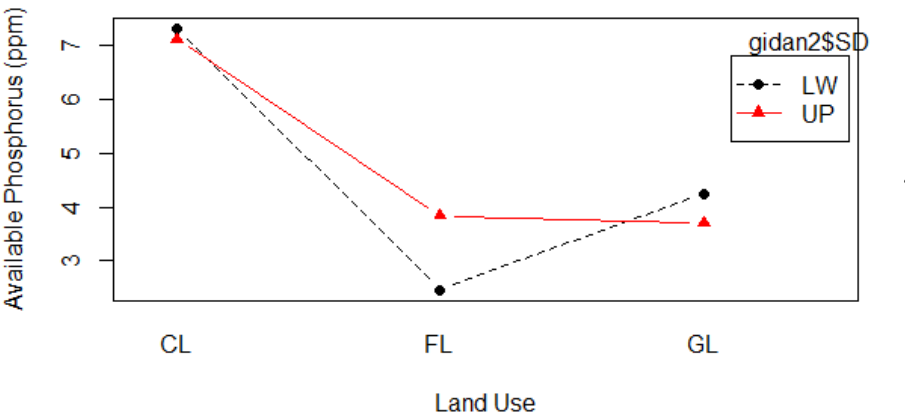

$* L W=$ Subsurface layer $; U P=$ Surface layer, $C L=$ Cultivated land, $F L=$ Bush land, $G L=$ Grazing Land

Figure 5: The effect of land uses and soil depths on available phosphorus

\subsubsection{Exchangeable Bases, Cation Exchange Capacity and Exchangeable Acidity}

The content of exchangeable calcium $\left(\mathrm{Ca}^{2+}\right)$ was significantly $(\mathrm{P} \leq 0.01)$ affected by the interaction of land uses by soil depths. Similarly, the content of exchangeable magnesium $\left(\mathrm{Mg}^{2}\right)$ was significantly $(\mathrm{P} \leq 0.001)$ affected by the interaction of land uses by soil depth (Table 3 and Figure 6$)$.

Table 3. Land use and soil depth effect on chemical properties of the soils in Abuhoy Gara watershed

\begin{tabular}{|c|c|c|c|c|c|c|c|}
\hline \multirow[t]{2}{*}{ Land use types } & \multirow{2}{*}{$\begin{array}{l}\text { Depth } \\
(\mathrm{cm})\end{array}$} & \multicolumn{6}{|c|}{ Exchangeable bases, cation exchange capacity and exchangeable acidity $(\mathrm{cmol}(+) / \mathrm{kg})$} \\
\hline & & $\mathrm{Ca}^{+}$ & $\mathrm{Mg}^{+}$ & $\mathrm{K}^{+}$ & $\mathrm{Na}^{+}$ & CEC & Ex. acidity \\
\hline \multirow[t]{2}{*}{ Cultivated } & $0-15$ & $4.73^{\mathrm{a}}$ & $1.83^{\mathrm{a}}$ & $0.47^{\mathrm{a}}$ & $0.25^{\mathrm{a}}$ & $13.94^{\mathrm{a}}$ & $0.263^{\mathrm{c}}$ \\
\hline & $15-30$ & $5.40^{\mathrm{a}}$ & $2.09^{\mathrm{ab}}$ & $0.84^{b}$ & $0.30^{\mathrm{abc}}$ & $15.15^{\mathrm{ab}}$ & $0.200^{\mathrm{b}}$ \\
\hline \multirow[t]{2}{*}{ Grazing } & $0-15$ & $5.97^{\mathrm{a}}$ & $2.90^{\mathrm{c}}$ & $1.15^{\mathrm{c}}$ & $0.32^{\mathrm{abc}}$ & $15.81^{\mathrm{ab}}$ & $0.043^{\mathrm{a}}$ \\
\hline & $15-30$ & $4.53^{\mathrm{a}}$ & $2.47^{\mathrm{abc}}$ & $0.85^{\mathrm{b}}$ & $0.38^{\mathrm{c}}$ & $17.19^{\mathrm{b}}$ & $0.045^{\mathrm{a}}$ \\
\hline \multirow{2}{*}{$\begin{array}{l}\text { Bush land (shrub } \\
\text { \& some trees) }\end{array}$} & $0-15$ & $11.43^{\mathrm{b}}$ & $5.13^{\mathrm{d}}$ & $2.08^{\mathrm{e}}$ & $0.34 b^{c}$ & $28.13^{\mathrm{d}}$ & $0.042^{\mathrm{a}}$ \\
\hline & $15-30$ & $7.20^{\mathrm{a}}$ & $2.84^{\mathrm{bc}}$ & $1.73^{\mathrm{d}}$ & $0.26^{\mathrm{ab}}$ & $25.20^{\mathrm{c}}$ & $0.025^{\mathrm{a}}$ \\
\hline Land (F value) & & 29.2826 & 73.462 & 232.143 & 8.0728 & 381.8734 & 171.1957 \\
\hline Land $-\operatorname{Pr}(>F)$ & & $2.194 \mathrm{e}-06 * * *$ & $2.197 \mathrm{e}-09 * * *$ & $1.405 \mathrm{e}-13^{* * * *}$ & $0.003144 * *$ & $1.819 \mathrm{e}-15^{* * *}$ & $1.934 \mathrm{e}-12 * * *$ \\
\hline $\begin{array}{l}\text { Soil depth (F } \\
\text { value) }\end{array}$ & & 10.5346 & 51.764 & 3.375 & 2.5520 & 0.0818 & 6.8640 \\
\hline $\begin{array}{l}\text { Soil depth - } \\
\operatorname{Pr}(>\mathrm{F})\end{array}$ & & $0.004488 * *$ & $1.073 \mathrm{e}-06 * * *$ & 0.08276 & 0.127562 & 0.7780748 & $0.01736 *$ \\
\hline $\begin{array}{l}\text { Land use x Soil } \\
\text { depth (F value) }\end{array}$ & & 7.6235 & 22.279 & 22.378 & 7.1200 & 13.4140 & 3.8318 \\
\hline $\begin{array}{l}\text { Land use } x \text { Soil } \\
\text { depth } \operatorname{Pr}(>F)\end{array}$ & & $0.003997 * *$ & $1.352 \mathrm{e}-05 * * *$ & $1.314 \mathrm{e}-05^{* * * *}$ & $0.005271^{* *}$ & $0.0002713 * * *$ & $0.04108 *$ \\
\hline $\operatorname{SEM}( \pm)$ & & 0.6289 & 0.1692 & 0.06 & 0.0192 & 0.4709 & 0.0120 \\
\hline
\end{tabular}

*Interaction means within a specific soil parameter followed by the same letter(s) are not significantly different from each other at $P \leq 0.05$; '***' 0.001 ; '**' 0.01 ; '*’ 0.05 ; SEM = Standard Error of Mean; CEC = Cation Exchange Capacity; Ex.Acidity $=$ Exchangeable Acidity

Exchangeable calcium $\left(\mathrm{Ca}^{2+}\right)$ was the highest $(11.43 \mathrm{cmol}(+) / \mathrm{kg}$ in surface soil and $7.20 \mathrm{cmol}(+) / \mathrm{kg})$ in subsurface soil under bush land and the lowest $(4.53 \mathrm{cmol}(+) / \mathrm{kg}$ in subsurface soil and $4.73 \mathrm{cmol}(+) / \mathrm{kgin}$ surface soil) under grazing and cultivated lands, respectively. Likewise, exchangeable magnesium $(\mathrm{Mg} 2+)$ was highest $(5.13 \mathrm{cmol}(+) / \mathrm{kg}$ in surface soil) under bush land and lowest $(1.83 \mathrm{cmol}(+) / \mathrm{kg}$ in surface soil) under cultivated land (Table 3). The contents of both exchangeable $\mathrm{Ca}^{2+}$ and $\mathrm{Mg}^{2+}$ were decreasing with soil depth in all land uses except bush land (Table 3). These indicate that there was higher down ward leaching of basic cations in the crop field than in the other land use practices. But in the subsurface soil, their values were declined probably due to leaching, decomposition, plant root uptake, runoff and erosion. The highest contents of $\mathrm{Ca}^{2+}$ and $\mathrm{Mg}^{2+}$ in bush land was may be attributed to leaves from plant falls, animal manures, macrofauna and soil microform and microbial activities common in this land use (Korkanc et al., 2008). The lowest 
value obtained on the cultivated land could be also be related to influence of intensity of cultivation and abundant crop harvest with little or no use of input as reported by Singh et al. (1995) and He et al. (1999). According to the rating set by Landon (1991), the calcium and magnesium contents of soils in the study area ranged from high in surface cultivated land to very high in surface bush land (Table 3 ).
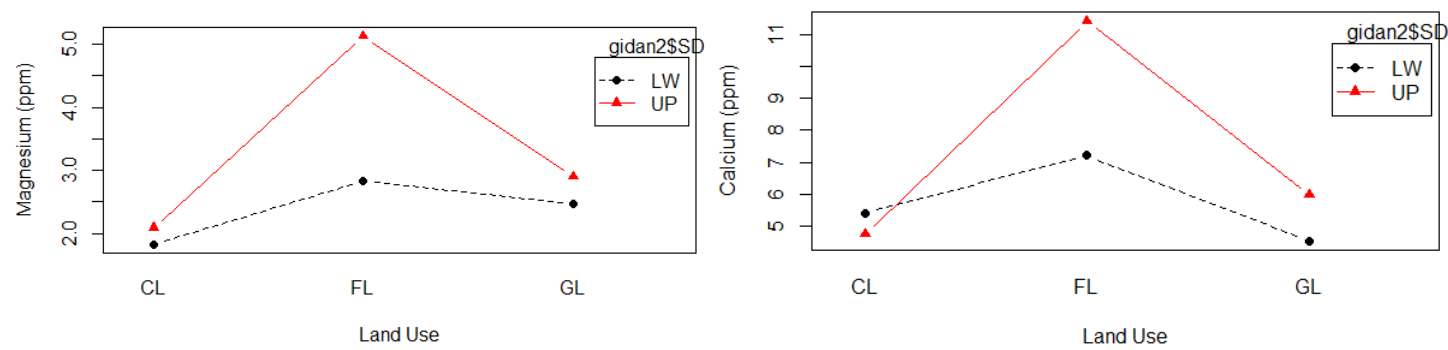

$* L W=$ Subsurface layer $; P=$ Surface layer, $C L=$ Cultivated land, $F L=$ Bush land, GL $=$ Grazing Land

Figure 6: The effect of land uses and soil depths on exchangeable $\mathrm{Ca}^{2+}$ and $\mathrm{Mg}^{2+}$

Exchangeable potassium $\left(\mathrm{K}^{+}\right)$content was significantly $(\mathrm{P} \leq 0.001)$ affected by the interaction of land uses by soil depths (Table 3). On the other hand, the content of exchangeable sodium $\left(\mathrm{Na}^{+}\right)$was significantly affected by interaction of land uses by soil depths $(\mathrm{P} \leq 0.01)$.Exchangeable potassium $\left(\mathrm{K}^{+}\right)$was highest $\left(2.08 \mathrm{cmol}_{(+)} / \mathrm{kg}\right.$ in surface soil) under bush land and lowest $\left(0.47 \mathrm{cmol}_{(+)} / \mathrm{kg}\right.$ in surface soil under cultivated land (Table 3 and Figure 7). Similarly, the highest $\left(0.38 \mathrm{cmol}_{(+)} / \mathrm{kg}\right.$ in surface soil) and the lowest $\left(0.25 \mathrm{cmol}_{(+)} / \mathrm{kg}\right.$ in surface soil $)$ exchangeable $\mathrm{Na}^{+}$contents were recorded at the bush and the cultivated lands, respectively. The percentage changes in $\mathrm{K}^{+}$and $\mathrm{Na}^{+}$contents of subsurface soil from surface soil were decreasing in all land uses. The highest content in the bush land was related with its high $\mathrm{pH}$ value and was in agreement with study results reported by Mesfin (1996) that high $\mathrm{K}^{+}$was recorded under the high $\mathrm{pH}$ tropical soils. In addition, the highest variability of $\mathrm{K}^{+}$ with depth under grazing land may be attributed to cattle manure supplied to the surface soil. The low exchangeable $\mathrm{K}^{+}$contents observed under cultivated land could probably due to continuous cultivations and inorganic farming practices in the study area which is supported by previous findings that indicate intensity of weathering, cultivation and use of acid forming inorganic fertilizers affect the distribution of $\mathrm{K}^{+}$in the soil system and enhance its depletion Malo (2005) and(Baker et al., 1997). The ranges of mean exchangeable $\mathrm{K}^{+}$values observed in this study show that $\mathrm{K}^{+}$was above the critical levels $\left(0.38 \mathrm{cmol}_{(+)} / \mathrm{kg}\right)$ for the production of most crop plants as indicated by Barber (1984). According to the rating set by Landon (1991), the $\mathrm{Na}^{+}$contents of soils in the study area is low.
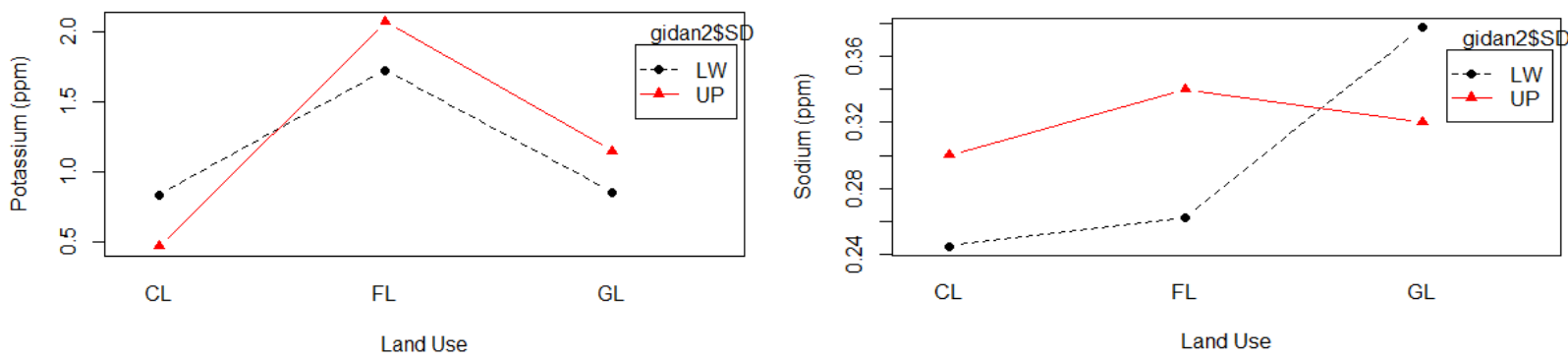

$* L W=$ Subsurface layer $; U P=$ Surface layer, $C L=$ Cultivated land, $F L=$ Bush land, $G L=$ Grazing Land

Figure 7: The effect of land uses and soil depths on exchangeable $\mathrm{K}^{+}$and $\mathrm{Na}^{+}$

The cation exchange capacity values of the soils in the study area were significantly $(\mathrm{P} \leq 0.001)$ affected by land use and the interaction of land usewith soil depth (Table 3 and Figure 8). Significant difference in cation exchange capacity contents due to the interaction of land use and soil depth was observed in the study area as highest $(28.13 \mathrm{cmol}(+) / \mathrm{kg})$ in surface soils of the bush land and lowest $(13.93 \mathrm{cmol}(+) / \mathrm{kg})$ in surface soils of the cultivated land. The cation exchange capacity values 
increased from the surface to the subsurface layer under different land use types except the bush land (Table 3).The highest cation exchange capacity in the surface layers of bush land use could be the result of the high organic matter accumulation, whilst the lowest cation exchange capacity at the surface layer of cultivated land use could be the result of leaching and down ward movement of organic matter and clay particles as was also reported by Fassil and Yamoah (2009). According to Landon (1991), the top soils having cation exchange capacity of $>25,15-25 \mathrm{cmol}_{(+)} / \mathrm{kg}, 5-15$ $\mathrm{cmol}_{(+)} / \mathrm{kg}$ and $<5 \mathrm{cmol}_{(+)} / \mathrm{kg}$ are classified as high, medium, low and very low, respectively. Based on the above ratings, the surface soils of the bush, the grazing and the cultivated lands qualify for high, medium and low status of cation exchange capacity, respectively (Table 3 ).

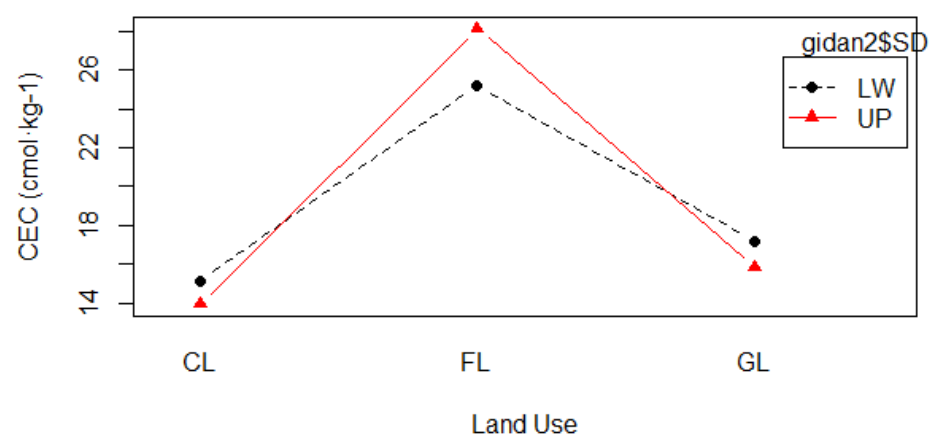

$* L W=$ Subsurface layer $; U P=$ Surface layer, $C L=$ Cultivated land, $F L=$ Bush land, $G L=$ Grazing Land

Figure 8: The effect of land uses and soil depths on cation exchange capacity (CEC)

The exchangeable acidity was significantly the interaction of land uses by soil depths (Table 3 and Figure 9). The highest $\left(0.263 \mathrm{cmol}_{(+)} / \mathrm{kg}\right.$ surface $)$ in the cultivated land and the lowest $(0.025$ $\mathrm{cmol}_{(+)} / \mathrm{kg}$ subsurface, $0.042 \mathrm{cmol}_{(+)} / \mathrm{kg}$ in surface, $0.045 \mathrm{cmol}_{(+)} / \mathrm{kg}$ in subsurface, $0.043 \mathrm{cmol}_{(+)} / \mathrm{kg}$ in surface) exchangeable acidity were recorded under the cultivated, bush and the grazing lands, respectively (Table 3). These results show that deforestation, intensive cultivation and application of inorganic fertilizers leads to the higher exchangeable acidity content under the crop field than others land uses. The results of this study were in agreement with those reported by different researchers (Baligar et al., 1997; Wakene, 2001), who reported that inorganic fertilizer application is the root cause of soil acidity.

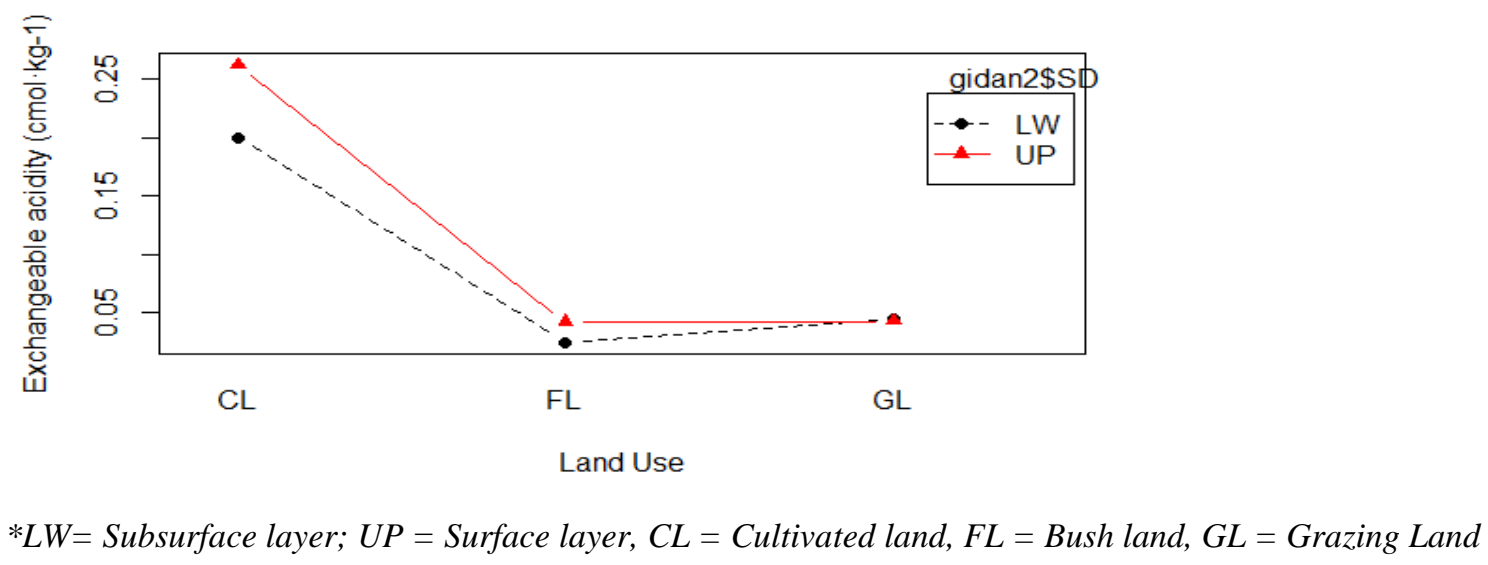

Figure 9: The effect of land uses and soil depths on exchangeable acidity

\subsection{Conclusions}

The soil organic matter and total nitrogen contents of soils in the study area ranged from very low to low/medium. In other words, results of the study indicate that the soil conditions in the cultivated land 
is getting below the condition of soils under bush and grazing lands. The interaction of land use with soil depth showed negative effects especially disturbance of soil nutrient status on cultivated land soils in surface soils. In general, the spatial variability of soil properties indicates the soil conditions were strongly affected by inappropriate land use, soil management practices and soil depth. Therefore, this study reinforces the sustainable land use by reducing intensity of cultivation, adopting integrated soil fertility management and application of organic fertilizers thereby maintaining the existing soil condition and replenish degraded soil properties.

\section{Acknowledgement}

The author would like to express his sincere thanks to Woldia University for their financial and logistics support. The staffs of Amhara National Regional State Sirinka Agriculture Center Laboratory are greatly acknowledged for their cooperation during soil analysis. Apart from that, he wants to express his appreciation to the Gidan District Agriculture office staff members for their unlimited contribution from site selection all the way up to sample collection.

\section{References}

Abebe, N., \& Endalkachew, K., (2012). The contribution of coffee agro-ecotype to soil fertility in Southwestern Ethiopia. African Journal of Agricultural Research, 7(1), pp. 74-81.

Adeboye, M., Bala, A., Osunde, A., Uzoma, A., Odofin, A., and Lawal, B., (2011). Assessment of soil quality using soil organic carbon and total nitrogen and microbial properties in tropical groecosystems, Journal of Agricultural Science (JAS), 2, pp. 34-40.

Agoume, V., Birang (2009). Impact of Land-use Systems on some Physical and Chemical Soil Properties of an Oxisol in the Humid Forest Zone of Southern Cameroon. Tropicultura 27: pp. 15-20.

Alemneh Dejene (2003). Integrated natural resources managements to enhance food security: the cases for community- based approaches in Ethiopia. Food and Agricultural Organization (FAO), the United Nations.

Ali, M. M., Shaheed, S. M., and Kubota, D., (1997). Soil degradation during the period 1967-1995 in Bangladesh. II. Selected chemical characteristics, Soil Sci. Plant Nutr., 43, pp. 879-890.

Aminu, Z., Yakubu, M., Mohammed, A. A., \& Kumar, N., (2013). Effect of land use on soil quality in Suleja, Niger State, Nigeria. Indian Journal of Leisure Science, 2(2), pp. 1-7.

Assefa, A. and Van Keulen, H., (2009). Modeling soil nutrient dynamics under alternative farm management practices in the Northern Highlands of Ethiopia, Soil Till. Res., 103, pp. 203-215.

Aung, Z. O., Win, K. T., Nguyen, L., \& Kimura, S. D. B., (2013). Topo sequential variation in soil properties and crop yield from double-cropping paddy rice in Northwest Vietnam. Journal of Cereals and Oilseeds, 4(5),pp. 65-75. Available at: http://dx.doi.org/10.5897/JCO2013.0109.

Bahrami, A., Emadodin, I., Atashi, M. R., \& Bork, H. R., (2010). Land use change and soil degradation: A case study, North of Iran. Agriculture and Biology Journal of North America, 1(4), pp. 600-605.

Baker, M.R., Nys, C. and Picard, J.F.,(1997). The effects of liming and gypsum application on a sessile oak (Quercus petraea) stand at Larcroix-Scaille (French Ardennes). I. Site characteristics, soil chemistry and aerial biomass. Plant and Soil. 150:pp. 99-10.

Baligar, V.C., Pitta, G.V.E., Gamma, E.E.G., Schafter, R.E., Filho A.F. and Clark, R.B., (1997). Soil acidity effects on nutrient use efficiency in exotic maize genotypes. Plant and Soil. 192:9-pp. 13.

Barber, S., (1984). Soil Nutrient Bioavailability: Mechanistic Approach. John Wiley and Sons. Inc., New York, USA.P. 398 . 
Baruah, T. C. and Barthakur, H. P., (1997). A text book of soil analysis. Vikas Publishing House. Pvt. Ltd. NewDelhi, India.

Berhanu, D. (1980). The physical criteria and their rating proposed for land evaluation in the highland region of Ethiopia. Land use planning and regulatory department, MoA, Addis Ababa, and Ethiopia 8(3): 19906145.

Black, C. A., Evans, D. D., White, J. L., Ensminger, L. E., and Clarkem, F. E., (1965). Methods of Soil Analysis, Part 2, American Society of Agronomy Inc., New York, WI.

Boke, S., (2004). Soil phosphorus fractions as influenced by different cropping systems in Andosols and Nitosols in Kembata-Tembaro and Wolayta Zones, p. 131.

Brady, N. C. and Weil, R. R., (1999). The Nature and Properties of Soils, $12^{\text {th }} e d n$., Prentice Hall, New Jersey.

Bremner D. C. and Mulvaney J. M., (1982). Total Nitrogen. In: Methods of Soil Analysis. (A. L. Page, R. H. Miller and D. R. Keaney, eds). Number 9 Part 2, Am. Soc. ofAgron.

Buol, S.W., (1997). Soil genesis and classification. The Iowa State University Press, Ammes, p. 360.

Cottenie, A., (1980). Soil and plant testing as a basis of fertilizer recommendations. FAO soil bulletin 38/2. Food and Agriculture Organization of the United Nations, Rome, Italy

Eyayu, M., Heluf, G., Tekaliign, M., and Mohammed, A., (2009). Effects of land use change on selected soilp roperties in the Tera Gedam Catchment and adjacent agro-ecosystems, Northwest Ethiopia. Ethiopian Journal of Natural Resources, 11(1), pp. 35-62.

Fassil, K., and Yamoah, C., (2009). Soil fertility status and numass fertilizer recommendation of Typic Hapluusterts in the Northern highlands of Ethiopia. World Applied Sciences Journal, 6(11), pp. 1473-1480.

Foth, H.D. and Ellis, B.G., (1997). Soil fertility, $2^{\text {nd }} E d$. Lewis CRC Press LLC., USA. p. 290.

Fungo, B. S., Grunwald, M. M., Tenywa, B., Vanlauwe, and Nkedi-Kizza, P., (2011). Lunnyu soils in the LakeVictoria basin of Uganda: Link to toposequence and soil type. African Journal of Environmental Scienceand Technology, 5(1), pp. 15-24.

Fu B L, C., (2000). The relationships between land use and soil conditions in the hilly area of the loess plateau in northern Shaanxi, China. Catena 39: pp. 69-78.

Jaiyeoba, I.A., (2001). Soil rehabilitation through afforestation: Evaluation of the performance of eucalyptus and pine plantations in a Nigerian savanna environment. 12:pp. 183-194.

Hall, R., (2008). Soil Essentials: Managing your Farm's Primary Asset, Landlinks Press, Collingwood.

He, Z.L., Alva, A.K., Calvert, D.V.,Li, Y.C.and Banks, D.J., (1999). Effects of nitrogen fertilization of grapefruit trees on soil acidification and nutrient availability in Riviera fine sand. Plant and Soil. 206:pp. 11-19.

Heluf, G., and Wakene, N., (2006). Effect of land use and management practices on chemical properties of somesoils of Bako areas, western Ethiopia. Ethiopian Journal of Natural Resources, 8(2), pp. 177-197.

Heshmati, M., Abdu, A., Jusop, S., and Majid, N. M., (2011). Effects of Land use practices on the organic carboncontent, cation exchange capacity and aggregate stability of soils in the Catchment Zones. AmericanJournal of Applied Sciences, 8(12), pp. 1363-1373. Available at: http://dx.doi.org/10.3844/ajassp.2011.1363.1373.

Hugo, L.P., Johann, B., Juergen, G., Hiremagalur, G., Mohammad, J., Victor, M., John, M., Martin, O., and Mohamed, S., (2002). Linking Natural Resources, Agriculture and Human Health: Case Studies from East Africa. LEISA Magazine supplement, pp. 17- 20. 
Islam, K. R. and Weil, R. R., (2000). Land use effects on soil quality in a tropical forest ecosystem of 15Bangladesh, Agriculture, Ecosystem and Environment (ELSEVIER), 79, pp. 9-16.

Korkanc, S. Y., Ozyuvaci, N., and Hizal, A., (2008). Impacts of land use conversion on soil properties20and soil erodiblity, J. Environ. Biol., 29, pp. 363-370.

Kumar, R., Rawat, K. S., \& Yadav, B., (2012). Vertical distribution of physicochemical properties under different toposequence in soils of Jharkhand. Journal of Agricultural Physics, 12(1), pp. 63-69.

Landon, J.R., (1991). Booker tropical soil manual: A Handbook for Soil Survey and Agricultural Land Evaluation in the Tropics and Subtropics. Longman Scientific and Technical, Essex, New York, USA, pp. pp. 1-474.

MacCarthy, D. S., Agyare, W. A., Vlek, L. G., and Adiku, G. K., (201). Spatial variability of some soil chemical and physical properties of an agricultural land scape, West African Journal of applied Ecology (AJOL), 21, pp. 47-61.

Malo, D.D., Schumacher, T.E., Doolittle, J.J., (2005). Long-term cultivation impacts on selected soil properties in the northern Great Plains. Soil Tillage Res 81: pp. 277-291.

Mesfin Abebe(1998). Alemaya University of Agriculture, Ethiopia.p. 272.

Mojiri, A., Aziz, H. A., \& Ramaji, A., (2012). Potential decline in soil quality attributes as a result of land use change in a hill slope in Lordegan, Western Iran. African Journal of Agricultural Research, 7(4), pp. 577-582.

Morgan, P. C., (2005). Soil Erosion and Conservation, $3^{\text {rd }} e d n$. ., Blackwell Publishing, Malden.

Mulugeta, L., Karltun, E., and Olsson, M., (2005). Assessing soil chemical and physical property responses to deforestation and subsequent cultivation in smallholders farming system in Ethiopia. Agriculture, Ecosystems and Environment, 105, pp. 373-386. Available at: http://dx.doi.org/10.1016/j.agee.2004.01.046.

Murphy, H.F., (1968). A report on the fertility status and other data on some soils of Ethiopia, Experiment Station Bulletin No. 44, College of Agriculture Dire Dawa, Ethiopia. p. 551.

Nega, E., and Heluf, G., (2009). Influence of land use changes and soil depth on cation exchange capacity and contents of exchangeable bases in the soils of Senbete watershed, Western Ethiopia. Ethiopian Journal of Natural Resources, 11(2), pp. 195-206.

Shiferaw Bole (2004). Soil phosphorous fractions influenced by different cropping system in Andosols and Nitisols in Kambata Tenbaro and Wolaita Zones, SNNPRS, Ethiopia. MSc Thesis Submitted to School of Graduate Studies, Alemaya University,Ethiopia, p. 126.

Taye, K., (2011). Chemical properties of wild coffee forest soils in Ethiopia and management implications. Agricultural Sciences, 2(4), pp. 443-450. http://dx.doi.org/10.4236/as.2011.24057.

Tekalign, T., (1991). Soil, plant, water, fertilizer, animal manure and compost analysis. Working document No. 13. International Livestock Research Center for Africa, Addis Ababa, Ethiopia.

Tekalign, M., Richter, C., \& Heiligtag, B., (2002). Phosphorus availability studies on ten Ethiopian Vertisols. Journal of Agriculture and Rural Development in the Tropics and Subtropics, 103(2), pp. 177-183.

Tematio, P., Tsafack, E., and Kengni, L., (2011). Effects of tillage, fallow and burning on selected properties and fertility status of Andosols in the Mounts Bambouto, West Cameroon. Agricultural sciences, 2(3), pp. 334-340. Available at: http://dx.doi.org/10.4236/as.2011.23044.

Van der, E.D., Janssen, B.H., and Oenema, O., (2006) Initial and residual effects of fertilizer phosphorus on soil phosphorus and maize yields on phosphorus fixing soils A case study in southwest Kenya. Agric Ecosys Environ 116: pp. 104-120.

Uriost, A.H., (2006) Cultivation effects on the distribution of organic carbon, total nitrogen and phosphorus in soils of the semiarid region of Argentinian Pampas. Geoderma 136: pp. 621-630. 
Wakene, N., (2001). Assessment of important physicochemical properties of DystricUdalf (DystricNitosols) under different management systems in Bako area, western Ethiopia. MSc Thesis Submitted to School of Graduate Studies, Alemaya University, Ethiopia, p. 93.

ZhaoQ, Z., (2008). Effect of Land Cover Change on Soil Phosphorus Fractions in Southeastern Horqin Sandy Land, Northern China Pedosphere 18: pp. 741-748.

Singh, C.J., Goh, K.M., Bond, W.J., and Freney, J.R., (1995). Effects of organic and inorganic calcium compounds on soil solution $\mathrm{pH}$ and $\mathrm{Al}$ concentration. European J. Soil Sci. 46:pp. 53-63.

McLean, E.O., (1982). Soil pH and lime requirement. In: Methods of soil analysis, Part 2. (Edited by A.L. Page, R.H. Miller and D.R. Keeney). American Society of Agronomy, Madison, Wisc, pp. 199224.

Nelson, D.W. and Sommers, L.E., (1982). Total carbon, organic carbon and organic matter: In: A.L. Page, R.H. Miller and D.R. Keeney) Methods of soil analysis. Part 2 Chemical and Microbiological Properties, pp.539-579.

Okalebo, J.R., Gathua, K.W. and Woomer, P.L., (1993). Laboratory methods of soil and plant analysis: A working manual - KARI - UNESCO - ROSTA, p.88.

Ryan, J., Estefan, G. and Rashid, A., (2001). Soil and plant analysis lab manual. $2^{\text {nd }} e d$. International Center for Agricultural Research in the Dryland Areas (ICARDA), Aleppo, Syria. National Agricultural Research Center, Islamabad, Pakistan.

Sumner, M.E. and Stewart, B.A., (1992). Soil Crusting: Chemical and Physical Processes. ${ }^{\text {st }} E d n$., Lewis Publishers, Boca Raton, ISBN-10: 0873718690, pp.372.

\section{Cite this article as:}

Gebeyaw, T. Y., 2019. Impact of Land Use Types and Soil Depths on the Distribution of Soil Physical and Chemical Properties in Soils of Aboy Gara Watershed, at Gidan District, North Wollo Zone, Ethiopia. Nigerian Journal of Environmental Sciences and Technology, 3(2), pp. 218-232. https://doi.org/10.36263/nijest.2019.02.0102 